\title{
Quality in the transport service
}

\section{Calidad en el servicio de transporte}

\author{
SÁNCHEZ-TRINIDAD, Rosa del Carmen, SÁNCHEZ-CRUZ, Samantha, CASTILLO-MÉNDEZ, \\ Rocío del Carmen and SÁNCHEZ-TRINIDAD, Adriana del Carmen
}

Universidad Popular de la Chontalpa

ID $1^{\text {st }}$ Author: Rosa del Carmen, Sánchez-Trinidad / ORC ID: 0000-0002-6614-0685, Researcher ID: AAG-7258-2020, CVU CONACYT ID: 390897

ID $1^{\text {st }}$ Coauthor: Samantha, Sánchez-Cruz

ID $2^{\text {nd }}$ Coauthor: Rocío del Carmen, Castillo-Méndez

ID $3^{\text {rd }}$ Coauthor: Adriana del Carmen, Sánchez-Trinidad

DOI: $10.35429 / J S R .2020 .17 .6 .1 .6$

Received January 10, 2020; Accepted April 01, 2020

\begin{abstract}
Due to the geographical location in which the municipality of H. Cárdenas Tabasco is located, it is considered the second most important city in the state, becoming the hub and strategic collection center of the Chontalpa area; It borders strategic cities that provide constant activity in the state economy, however, according to the Municipal Development Plan of H. Cárdenas Tabasco (2013-2015), it is determined that the problems of the study area are extensive and the Municipality must solve them in a strategic way, some of these problems are; population growth, the creation of health campaigns that provide for the reproduction of children at an early age in young people and adolescents, this leads to rapid urbanization; in which there is a transport traffic in which the roads and streets must be suitable, have their respective signs and a constant road flow; in matters of security, strict measures are needed, focused on the protection of citizens and their belongings; The lack of interest in the professional education of the reside nts and the aforementioned factors creates a hostile environment for the commercialization companies, continuous transformations must be generated to strengthen the business sector that will contribute to the development of the municipality.
\end{abstract}

Quality, Service, Transport, Tailoring

\begin{abstract}
Resumen
Debido a la ubicación geográfica en la que se encuentra el municipio de H. Cárdenas Tabasco, es considerada la segunda ciudad más importante del estado, convirtiéndose en el centro y centro estratégico de recolección de la zona de Chontalpa; Limita con ciudades estratégicas que proporcionan actividad constante en la economía del Estado, sin embargo, según el Plan de Desarrollo Municipal de H. Cárdenas Tabasco (2013-2015), se determina que los problemas del área de estudio son extensos y el Municipio debe resolverlos de manera estratégica, algunos de estos problemas son; crecimiento de la población, la creación de campañas sanitarias que prevén la reproducción de niños a una edad temprana en jóvenes y adolescentes, lo que conduce a una rápida urbanización; en el que hay un tráfico de transporte en el que las carreteras y calles deben ser adecuadas, tener sus respectivas señales y un flujo de carretera constante; en materia de seguridad, se necesitan medidas estrictas, centradas en la protección de los ciudadanos y sus pertenencias; La falta de interés en la educación profesional de la nts y los factores antes mencionados crean un ambiente hostil para las empresas de comercialización, se deben generar continuas transformaciones para fortalecer el sector empresarial que contribuirá al desarrollo del municipio.
\end{abstract}

Calidad, Servicio, Transporte, Sastrería

Citation: SÁNCHEZ-TRINIDAD, Rosa del Carmen, SÁNCHEZ-CRUZ, Samantha, CASTILLO-MÉNDEZ, Rocío del Carmen and SÁNCHEZ-TRINIDAD, Adriana del Carmen. Quality in the transport service. Journal of Social Researches. 2020. 6-17: 1-6.

\footnotetext{
* Correspondence to Author (Email: rosa.sanchez@upch.mx)

$\dagger$ Researcher contributing as first author.
} 


\section{Introduction}

In Mexico, the regulator of public transport services is the Ministry of Communication and Transportation [SCT] through laws and controls exclusive to carriers; according to its law, a public passenger and / or freight transport service, is one that is carried out continuously, uniformly, regularly and permanently on the public land communication roads of the State, to meet the demand of users, through the use of appropriate vehicles for each type of service, and in which the users as consideration, make a payment in the cash register, in accordance with the previously approved rates. The service provider may be a state entity, individual or legal entity with lucrative fines, authorized to provide the service (Transportation Law for the State of Tabasco, 2015; article 22, page 7).

The Transportation Law (2015) classifies passenger, cargo and mixed transport services (Page 8), each of these accounts with its statutes which controls and regulates its functions and activities, Tabasco has each of these services which facilitate the mobility or the transfer of citizens from one place to another to carry out the activities of a society.

The city of Cárdenas, Tabasco has an exclusive Union of workers who own taxis, radio taxis, similar and related, whose motto is "For the greatness of our Union and the solidarity of the workers at the wheel, with a spirit of service". The taxi in many cities is considered a luxury product, in Cárdenas Tabasco this concept is lacking because the same union does not consider it as such, for this organization the taxis are classified into four areas that are: special service, collective service, service for people with different abilities, and radio taxi service. Then describe each of them.

A special service is one that is carried out in a personalized way, with a fixed destination, its cost is variable, it depends on the sector you wish to reach.

A collective service is one in which more than two users are transferred with a different destination, its cost is defined by the organization and cannot suffer any alteration.
A service for people with different abilities, is one that is performed with a special unit which is modified for the transportation of users with some physical motor impairment, this service becomes personalized and it can be said that until special, its cost is the variable .

A radio taxi service is one that the user can request by means of a telephone call, this is personalized and considered as special, its cost is variable this depends on the sector where it is requested.

Knowing and identifying this classification allows to have a broad and concrete overview of the service that the taxi union offers to its users, each of these services has its specifications which will be cleared during the investigation. The service offered by the driver is considered the main factor for this to have a constant demand in the market, therefore this research work is focused on determining the perception of the quality of the service that is offered to the user by the taxi union mentioned above.

\section{Methodology to develop}

Systematic quantification of the quality that the client perceives of a service is not an easy task. Tools are needed to help companies better understand the meaning of customer value, as well as the degree to which their efforts are meeting their needs and expectations. The constant change in the behavior of markets and consumers, forces companies to have updated information on which their decision-making will depend, this information is compiled and interpreted in a consistent way allowing to identify and define the problem and skills that a company has ; Organizations identify this function as market research. For the development of this research work, an exhaustive literary review was first made regarding issues such as marketing, services, service marketing, quality of services; the main primary sources such as books, specialized journals, research articles, the instrument used for the collection and organization of information was consulted through the use of bibliographic records, this instrument was used to sort, classify the information collected, all this in order to obtain data that support and support the scientific theories applied to this research project. 
Subsequently, an analysis of the current situation of the municipality of $\mathrm{H}$. Cárdenas Tabasco was carried out to have an informed diagnosis, through the consultation of official information portals such as INEGI, the municipal development plan, town hall, and sedesol; The instrument to be implemented will be the collection and organization of catalogs, databases, search engines and web sites on the Internet. Knowing and investigating the study universe allows us to have a broader picture of the needs or advantages that can be obtained in the performance of a service

The services have special characteristics, which are taken into consideration by the clients to form a judgment regarding their quality, which is why an accurate investigation of the study area was then carried out, through an interview (see appendix 1) with the general secretary of the taxi union Mr. Miguel Ángel Pérez López; The instrument used a semistructured questionnaire, data collection sheets (see Appendix 2) to know the conditions of each of the transport units, a general inventory of resources available to the company. For the identification of the facilities a personal visit was made and through the observation it was possible to identify the conditions of their facilities. Through the visit, general data of the facilities, personnel and the service offered to the aforementioned municipality were obtained. Finally, the SERVQUAL measuring instrument was applied to the end users of the service, this field investigation was quantitative, since the final results will be expressed completely numerically by means of scatter plots, on the other hand according to the research perspective This is completely descriptive because it is intended to know how satisfied customers are with the service provided by the taxi union of the city of Cárdenas Tabasco, in regard to the design of the study, this is of a non-experimental transactional cut because data will be collected in A single moment of time.

\section{Results}

A service is not an intangible element in its entirety, it has tangible elements such as physical facilities, equipment, personnel and communication material, the sum of all of them is the result of activities generated by the supplier to satisfy the customer.
The intangible part of a service causes its quality measurement to be empirical, based on perceptions that customers have experienced.

To achieve the quantification of the service and determine its quality, the authors ZEITMAN, BITNER and GREMLER (2009) present a practical practical measuring instrument Servqual; which is used and adapted to this research, the aforementioned instrument not only focuses on measuring the perceived perceptions of the client, but also measures the quality of the company, the measurement is carried out with a semi-structured questionnaire of 22 reagents proposed by the authors (see appendix ---), divided into five fundamental dimensions that are; reliability, sensitivity, security, empathy and tangible elements, which allow defining the quality offered to the client.

The analysis of the data obtained was carried out through frequency distribution, allows to know the frequency of the observations or occurrences with which the same value is presented in a sample; Therefore, this research presents the frequencies obtained (see table 2) of the survey conducted to our study group with reference to the perception of the quality that the union of workers who own car taxis, radio taxis, similar and related offers to citizens of the municipality of H. Cárdenas Tabasco.

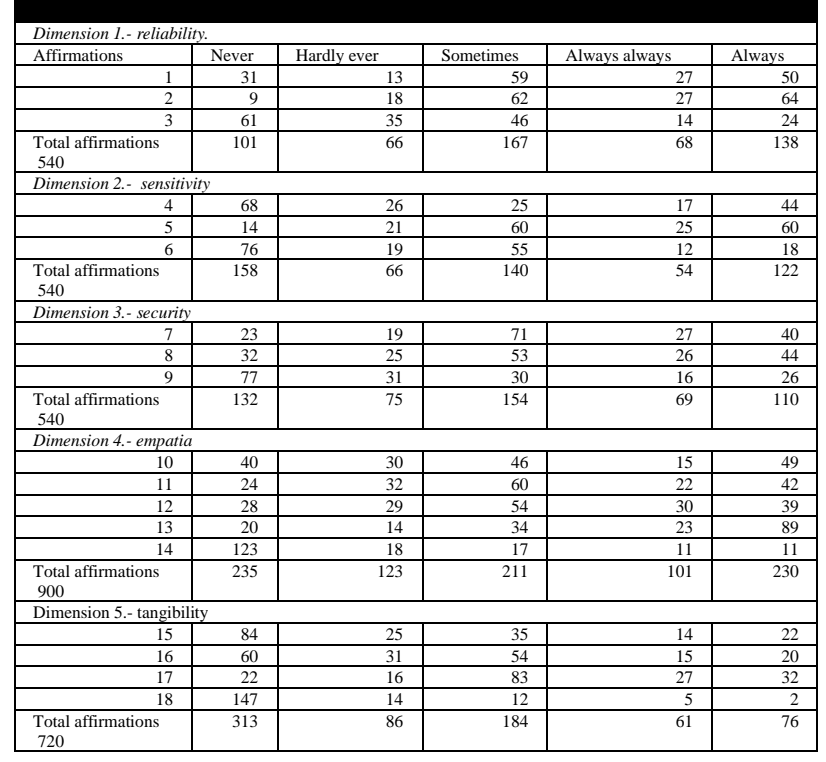

Table 1 Frequency by affirmation Source: self made 
Once the data was analyzed using descriptive statistics, a scatter plot was made that quantifies the degree to which the data tends to be grouped around an average value, this type of graph was used to visualize the results because it is what they suggest the authors Parsu Parasuman, Valarie Zeithaml and Leonard Berry; This allows us to analyze a representative subset called a sample, selected from the population under study.

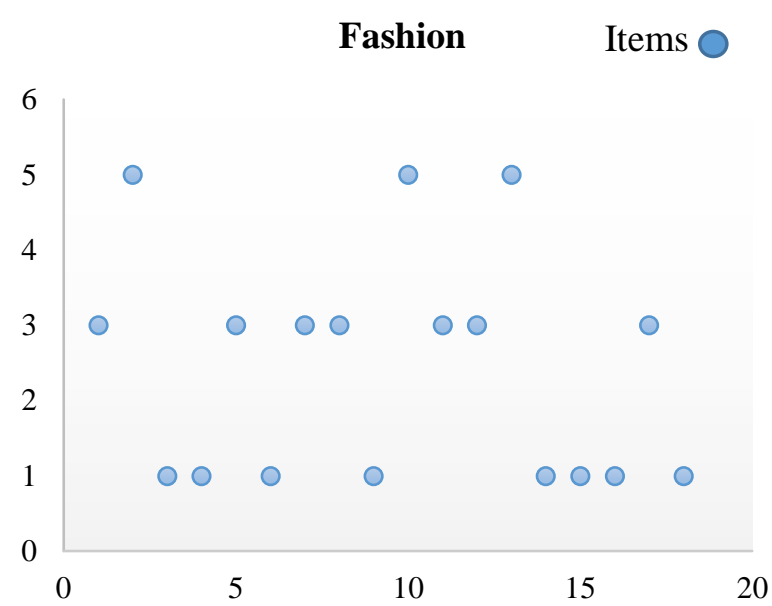

Figure 1 Scatter plot by Items Source: self made

The relevant factors that the service quality model mentions are considered the main part of this investigation, these factors determine the user's perception of the service offered; For the above mentioned our variables that in this case have been listed from 1 to 5 , where 1 is never, 2 is almost never, 3 is sometimes, 4 is almost always and 5 is always; these have a constant variation that was quantified in a relative way and is assigned the frequency name, with which the constant frequency with which the variables have been selected by the users is demonstrated allowing also to know the cumulative frequency that exists between the dimensions of the model used.

Even when the frequency with which the users determined the position of the variables of this investigation is counted, the decision has been made to have descriptive parameters or measures that summarize the tendency, distribution and / or repetition of the set of data obtained; Just like the well-known central tendency, this is selected because it allows us to locate the central point of a set of data, these are the mean, median and mode.

\begin{tabular}{|r|r|r|r|}
\hline \multicolumn{1}{|c|}{ Affirmations } & \multicolumn{1}{l}{ Half } & Median & Fashion \\
\hline 1 & 3.3167 & 3 & 3 \\
\hline 2 & 3.661 & 4 & 5 \\
\hline 3 & 2.472 & 2 & 1 \\
\hline 4 & 2.667 & 2 & 1 \\
\hline 5 & 3.522 & 3 & 3 \\
\hline 6 & 2.311 & 2 & 1 \\
\hline 7 & 3.222 & 3 & 3 \\
\hline 8 & 3.139 & 3 & 3 \\
\hline 9 & 2.328 & 2 & 1 \\
\hline 10 & 3.01 & 3 & 5 \\
\hline 11 & 3.133 & 3 & 3 \\
\hline 12 & 3.128 & 3 & 3 \\
\hline 13 & 3.81667 & 4 & 5 \\
\hline 14 & 1.739 & 1 & 1 \\
\hline 15 & 2.244 & 2 & 1 \\
\hline 16 & 2.483 & 2.5 & 1 \\
\hline 17 & 3.1722 & 3 & 3 \\
\hline 18 & 1.3389 & 1 & 1 \\
\hline & & &
\end{tabular}

Table 2 Scatter plot by Items

Source: self made

\section{Gratitude}

Popular University of Chontalpa.

\section{Conclusions}

The collection of data and information is simple if you talk about the quality of products, however in the quality of services this function is not an easy task, since this depends entirely on the subjectivity of the consumer; There are many measurement models that determine the quality of a company, but the one that most adapted to this research is the service quality model that allowed us to analyze the general objective of this research which is to determine the perception of the quality offered by the union of workers who own cars, taxis, radio taxis, similar and related of the municipality of $\mathrm{H}$. Cárdenas Tabasco.

The conclusions derived from this research allow us to verify that the specific silver objectives have been theoretically and statistically based, giving credibility to what is expressed here. Such is the case of the first objective in which you can find the theoretical concepts related to marketing where it is clarified that this concept not only handles advertising issues of a company as the vast majority of people think; This is a more complex concept that controls, gives alternatives and prevents essential movements in a company. 
This concept is adapted both to the commercialization of products and services, such is the case of this research where services is the main variable, which has allowed the quantification of the perception that the user has of the company; Theoretically, services are actions that a person offers to another, their heterogeneity is their main advantage, this can give a high value to others if it is well directed.

For a company to be a leader in its union, it must remain in constant demand and this can only be possible exceeding the expectations of its users; To be able to keep on this record, the administrators manage a fundamental concept that allows to create, restructure and innovate the strategies that govern your company, said concept is quality; Through the control and mediation of this, the perception and expectations that the user has of the product or service that is being marketed are known. Once the research theory was founded, a diagnosis of the municipality of Cárdenas Tabasco was necessary, where the history, demography, and economic sectors that make up the municipality can be found; This allowed us to clear objective number two, which presents a broad overview of the social and economic structure of this municipality. The findings of this diagnosis allow us to see the deficit that exists in each of the sectors, this caused by the lack of interest of the same inhabitants; citizens have lost the sense of belonging and overcoming, labor apathy leads them to abandon their lands, their crops, their businesses without realizing that it is the only thing that allows them to survive economically and maintain an optimal standard of living. The government creates options and provides investment for each of the economic sectors of the municipality, it is a matter of the citizen having their own aspiration and initiative, which does not intend to divert their qualities in activities that are unknown; that is to say that the farmer does not turn on leaving his land for an office, or that the clerk stops performing his duties pretending to be the owner of the company for which he works, if each person specializes or is guided in the activity he wishes to perform This achieves eminent success, in which not only one is the beneficiary, because in every activity there is an economic interaction that allows it to achieve its objectives.
This makes it clear that for the existence of an economic balance in the municipality, both the human factor and the government are needed, since these are the constant in a productive society.

\section{References}

ANDRÉS F.J.M. Ferrando (2008) "Marketing in service companies". Mexico Alfaomega.

ADI Sharón / GABRIEL Weil (2003) "Measuring the quality of services"; CEMA University.

CRISTOPHER Lovelock / JOCHEN Wirtz (2008) "Service Marketing" (personnel, technology and strategies) sixth edition; Pearson Prentice Hall, pages 418,419 and 420.

CHARLES, M., Ziv, G., Bohrer, G., \& Bakshi, B. R. (2020). Connecting air quality regulating ecosystem services with beneficiaries through quantitative serviceshed analysis. Ecosystem Services, 41, 101057.

DE GRUYTER, C., Truong, L. T., \& Taylor, E. J. (2020). Can high quality public transport support reduced car parking requirements for new residential apartments?. Journal of Transport Geography, 82, 102627.

DOUGLAS H.K. \& E.G.B (2012). "Service marketing concepts, strategies and cases. Mexico". Cengage Learning.

ELIZBETH Velázquez Velázquez, (2012) "Marketing of goods and services" first edition; Red third milnio S.C.

GUSTAVO Fadda, 2013, WTO chair, Argentine Flacso.

GRÖNROOS C. (1994) Marketing and service management. Spain Diaz de santos.

KAROŃ, G., \& Żochowska, R. (2020). Problems of Quality of Public Transportation Systems in Smart Cities-Smoothness and Disruptions in Urban Traffic. In Modelling of the Interaction of the Different Vehicles and Various Transport Modes (pp. 383-414). Springer, Cham. 
LAURA Fisher / JORGE Mirror (2004) "Marketing" third edition, MC.GRAW - WILL. PUBLISHING MARKETING. (1998) "Service design: step by step". (1 $\alpha$ ed.). Spain: Editorial Díaz de Santos.

LI, W., Peng, Q., Wen, C., Li, S., Yan, X., \& Xu, X. (2020). Integrated Optimization on Energy Saving and Quality of Service of Urban Rail Transit System. Journal of Advanced Transportation, 2020.

PHILIP Kotler / GARY Armstrong, (2005) "Fundamentals of Marketing" fourth edition; Prentice - Halli, hispanoamericana, S.A.

ZEITMAN, BITNER AND GREMLER (2009) "Service Marketing, fifth edition, editorial Mc Graw Hill 